\title{
Homenagem ao professor José Luiz de Andrade Rezende
}

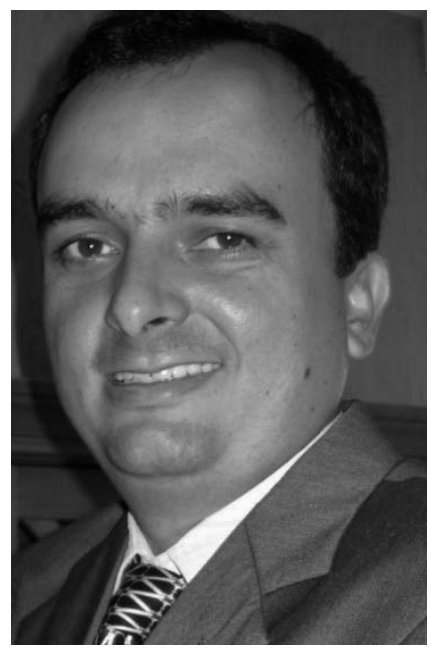

O professor José Luiz de Andrade Rezende Pereira é natural de Pouso Alegre, Minas Gerais, e ingressou na graduação em engenharia agronômica na Universidade Federal de Lavras (UFLA) no ano 2000. Na mesma universidade, concluiu mestrado em viabilidade técnica e econômica do milho safrinha no Sul de Minas Gerais em 2007 e formou-se no doutorado em melhoramento de milho para produção de silagem em 2010.

Enquanto completava sua formação acadêmica, trabalhou por dois anos como desenvolvedor de produtos na Dow Agrosciences, e foi responsável pela primeira liberação técnica dos transgênicos dessa empresa multinacional no país.

Em abril de 2010, José Luiz redirecionou sua carreira: tornou-se professor do IFSULDEMINAS, campus Inconfidentes, onde leciona em cursos técnicos e graduações, em disciplinas de fitotecnia e conservação do solo. "Passei a dedicar-me integralmente ao ensino, à pesquisa e à extensão, e me sinto realizado por fazer isso no IFSULDEMINAS".

Além da formação dos discentes em sala de aula, o professor José Luiz atua como representante docente no Núcleo Institucional de Pesquisa e Extensão (NIPE) e na Câmara de Pesquisa, Pós-Graduação e Inovação (CAPEPI).

$\mathrm{Na}$ área de comunicação científica, José Luiz participa da comissão editorial da Revista Agrogeoambiental e colabora como avaliador de periódicos nacionais e internacionais, tais como Revista Ceres, Revista Brasileira de Milho e Sorgo e Revista Scientia Plena.

É um dos organizadores do IFSHOW, evento de transferência de tecnologia do campus Inconfidentes que faz a aproximação entre sociedade e ambiente acadêmico. "Na área de pesquisa, nosso desafio é gerar conhecimento científico que promova desenvolvimento regional", explica José Luiz, que coordena projetos de pesquisa executados no IFSULDEMINAS em parceria com outras instituições e financiados pela FAPEMIG e CNPq. 